\title{
RETARDATION EFFECT ON THERMALLY-MODIFIED SPRUCE WOOD
}

\author{
LINDA MAKOVICKÁ OSVALDOVÁ ${ }^{1} \&$ MILAN GAFF ${ }^{2}$ \\ ${ }^{1}$ Faculty of Security Engineering, University of Zilina, Slovakia \\ ${ }^{2}$ Faculty of Forestry and Wood Sciences, Department of Wood Processing, \\ Czech University of Life Sciences in Prague, Czech Republic
}

\begin{abstract}
The subject matter of this paper is spruce wood (Picea abies L.). The thermal treatment of wood (thermal wood) is a new technology of wood treatment, improving its physical and biological properties and increasing its resistance to biological wood-destroying agents and atmospheric effects. Its fire and technical properties, capability to set it on fire and burn it have been studied less. Research in the aforementioned subject is the subject matter of this paper, together with an option to treat this thermally treated wood with a standard commercial retardant. Experimental equipment was non-standardized laboratory equipment using a flame source of higher intensity (flame burner - propane-butane) affecting the test sample in an open environment. This is a simulation of actual fire. The evaluative criteria for both tests, thermally treated wood $\left(20^{\circ} \mathrm{C}, 160^{\circ} \mathrm{C}, 180^{\circ} \mathrm{C}, 210^{\circ} \mathrm{C}\right)$ without retardant treatment and with retardant treatment, were weight loss and burning rate. The data results are presented in the tables and diagrams and are statistically evaluated. The aforementioned results will be used for the complex evaluation of spruce wood treated this way and a new view will be taken on wood treated this way from a fire prevention point of view.
\end{abstract}

Keywords: conservation, domed mosques, morphology, Ottoman mosques, preservation, typology.

\section{INTRODUCTION}

Among all construction materials, wood has the best weight-to-load capacity ratio, which makes it possible to implement it into wooden constructions in hard-to-access areas. The material is used in the exterior as well as the interior of wooden constructions. The main disadvantage of the material is its ignitability; therefore, much attention is paid to increase its fire protection properties. Methods of treatment which modify the basic properties of the material are called modification methods. The interest in thermally modified wood has significantly increased lately. This interest aroused due to reduced production of durable wood material, an increased interest in durable construction material and legislative changes, which restrict the use of toxic substances. At present, the largest commercial importance is represented, in particular, by five different modifications, one in Finland, the Netherlands (Plato wood) and Germany (oil heat, OHT) [1]-[4].

Some new methods are being developed in Denmark (WTT) and Austria (Huber Holz). Some of these processes are still being introduced, others have already been put into operation. Various types of wood are used with different technological conditions depending on the type of tree and the end use. Temperatures range between $160^{\circ} \mathrm{C}$ and $260^{\circ} \mathrm{C}$ and the differences between various modifications arise when using gas environment (nitrogen, steam), oils, different humidity levels, etc. Wood treated in such way has more appropriate properties when used in the exterior and the interior, e.g. dimensional stability, durability, colour change, and so on [5]-[7].

The effect of thermal modification on anatomical, mechanical, physical, biological and chemical properties of wood has been the subject of many studies, in scientific literature, however, no knowledge about fire characteristics of this material is available. Fire characteristics are important especially in terms of its use in wooden constructions [8], [9]. 
Even though there are studies dealing with the issue of thermo wood burning [10], the information on thermo wood fire modifications and the effect of these modifications on its properties is missing.

The objective of the paper is to evaluate different thermal modifications and the influence of fire retardant on thermally modified wood, under conditions that simulate the natural process of wood burning with a heat source, permanent air flow and exhaust gas flow.

\section{EXPERIMENT}

The test specimens of thermally modified spruce wood of $200 \mathrm{~mm}$ (longitudinal cut) $\times 100 \mathrm{~mm} \times 20 \mathrm{~mm}$ were thermally modified in the same way and divided into two groups, where one of group was treated by a fire retardant. The samples of thermally modified spruce wood (Picea abies L.), at temperatures ranging between $20^{\circ} \mathrm{C}$ and $160^{\circ} \mathrm{C} ; 180^{\circ} \mathrm{C}$ and $210^{\circ} \mathrm{C}$, were labelled as P (samples P-160, P-180, and P-210), and the second set of test-bodies made up of thermally modified spruce wood treated with a fire retardant were labelled as S (S-20, S-160, S-180, and S-210) (please see Fig. 1).

The process of thermal modification was carried out as follows (please see Table 1):

1. Heating and drying - in this stage, the temperature increases rapidly in an oven at about $100^{\circ} \mathrm{C}$ to support the action of steam. Then, the pitch decreases and increases to the level of $130^{\circ} \mathrm{C}$. Drying medium is hot air or hot steam. Throughout this phase, the wood is dried to approximately zero moisture.

2. Thermal modification - in the second stage the temperature is raised to the level of $185^{\circ} \mathrm{C}-230^{\circ} \mathrm{C}$ for $2-3$ hours. The height of temperature and duration of action are determined by the requirements of the class of products THERMOWOOD (Thermo-S and Thermo-D).

3. Refrigeration and air conditioning - in the third phase, the thermally modified wood is gradually cooled to a temperature of $80^{\circ} \mathrm{C}-90^{\circ} \mathrm{C}$ and the humidity is stabilized so that the final moisture level was normal $4-7 \%$.

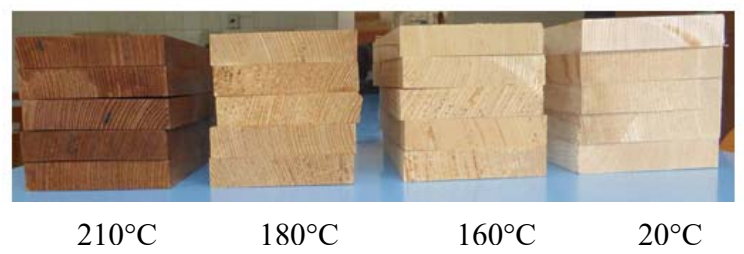

Figure 1: Test specimens (S-210, S-180, S-160 and S-20).

Table 1: Input technological parameters and thermal modification process.

\begin{tabular}{|l|l|l|l|}
\hline \multicolumn{4}{|l|}{ Input technological parameters } \\
\hline Wood moisture & 2 to $4 \%$ \\
\hline Filled kiln capacity & $0.8 \mathrm{~m}^{3}$ \\
\hline Maximum temperature achieved & $210^{\circ} \mathrm{C}$ & \multicolumn{2}{|l|}{} \\
\hline & Thermal modification process \\
\hline & $160^{\circ} \mathrm{C}$ & $180^{\circ} \mathrm{C}$ & $210^{\circ} \mathrm{C}$ \\
\hline Heating & 6.3 hours & 4.5 hours & 4.8 hours \\
\hline Thermisation & 4.4 hours & 5.3 hours & 6.7 hours \\
\hline Cooling & 1.7 hours & 2.4 hours & 4.2 hours \\
\hline Total modification time & $\mathbf{1 2 . 4}$ hours & $\mathbf{1 2 . 2}$ hours & $\mathbf{1 5 . 7}$ hours \\
\hline
\end{tabular}


The average density values of the test-bodies are shown in Table 2 .

\subsection{Fire retardant}

Fire retardant FLAMGARD TRANSPARENT was applied onto the samples. It is a viscous coating which, after drying, is transparent with light yellowish tinge, retaining the original lines of the wood. During the burning process, fire coating produces - by its thermal decomposition on the surface of the treated material - a thick, non-combustible, heat-insulating foam layer causing time delays and therefore reliably protecting the material against fire and radiation heat source. One minimum layer of fire retardant coating has been applied. More information about fire retardant absorption is discussed in the section 4 of this paper.

\section{METHODS}

This study tested a new method of evaluating the burning, which was divided into two phases. The first phase consisted of the direct exposure of the test specimen to a gas burner for $10 \mathrm{~min}$. The test specimen was placed under the burner at a $45^{\circ}$ horizontal angle. The size of the flame was $10 \mathrm{~cm}$ from the mouth of the burner, and it was placed at the centre of the underside of the test specimen (please see Fig. 2).

The distance from the mouth of the burner to the centre of the sample was $9 \mathrm{~cm}$. In the second phase (after $10 \mathrm{~min}$ ), the flame was removed from the sample, and the weight loss and burning rate was recorded for another $5 \mathrm{~min}$. The goal of the second phase was to record the course of burning. Thermal degradation can continue to develop in the glowing layer of the wood, resulting in self-ignition, re-ignition, and sustained charring. This method of evaluation was meant to simulate the natural wood-burning process with a flame source, sustained air supply, and free flow of combustion gases [11], [12]. The device consisted of a USBEC 1011/1 propane burner (DIN-DVGW- Reg. Mr. NG-2211AN0133, blasting, $1.7 \mathrm{~kW}$, Dresden, Germany), propane tank, electric scales (MS 1602S/MO1, Mettler Toledo, Geneva, Switzerland), and BalanceLink 4.2.0.1 software [13], [14] to record the wood's weight.

With continuous weighing during the flammability test, the weight loss of the test specimens was recorded at a regular interval of $10 \mathrm{sec}$. The average burning rate and weight loss were calculated from the measured values by eqns (1) and (2), respectively.

The obtained data was evaluated with Excel software (Microsoft, Redmond, WA, USA). The entire course of burning is described in graphs that capture the $15 \mathrm{~min}$ burning of the test specimen.

Table 2: Average density values.

\begin{tabular}{|l|l|l|l|l|l|}
\hline \multicolumn{2}{|c|}{ Thermal modification } & $20^{\circ} \mathrm{C}$ & $160^{\circ} \mathrm{C}$ & $180^{\circ} \mathrm{C}$ & $210^{\circ} \mathrm{C}$ \\
\hline \multirow{2}{*}{$\mathrm{P}$} & Density $\left(\mathrm{kg} / \mathrm{m}^{3}\right)$ & 447 & 445 & 452 & 430 \\
\cline { 2 - 6 } & Moisture content (\%) & 2.9 & 2.8 & 2.8 & 2.8 \\
\hline \multirow{2}{*}{$\mathrm{S}$} & Density $\left(\mathrm{kg} / \mathrm{m}^{3}\right)$ & 453.8 & 461 & 461.2 & 469.2 \\
\cline { 2 - 6 } & Moisture content (\%) & 2.8 & 2.8 & 2.9 & 2.8 \\
\hline
\end{tabular}




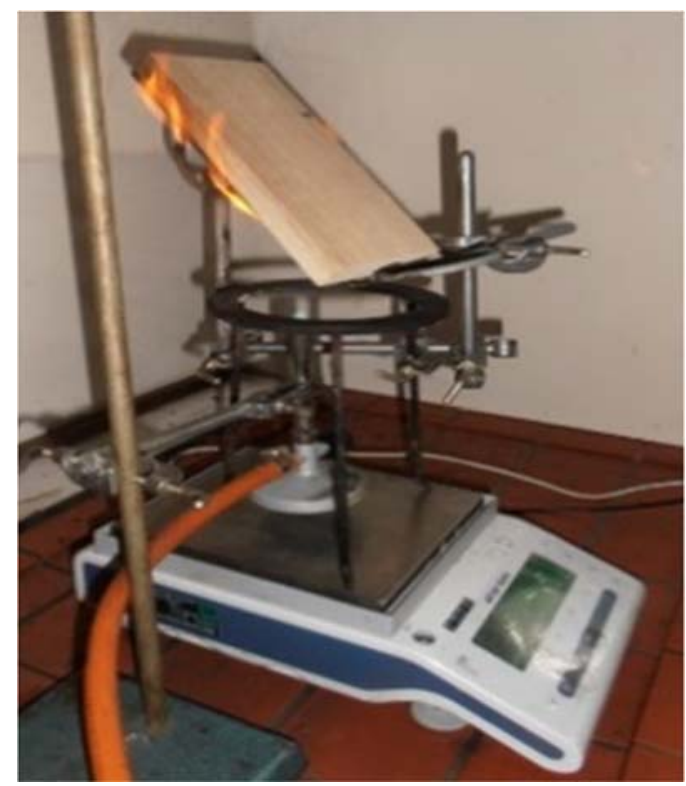

Figure 2: Testing equipment.

Weight loss and burning rate were the two evaluation criteria (1) and (2): The weight loss was calculated according to eqn (1):

$$
\Delta m=\frac{m_{1}-m_{2}}{m_{1}} \cdot 100
$$

- $\Delta m$ is the weight loss (\%).

- $m_{1}$ is the sample's weight before the test $(\mathrm{g})$.

- $m_{2}$ is the sample weight after the test $(\mathrm{g})$.

The burning rate was calculated using eqn (2):

$$
v=\frac{m_{t}-m_{t}+10}{m_{t 0} \cdot 10} \text {. }
$$

- $\quad v$ is the burning rate $(\% / \mathrm{s})$.

- $m_{t}$ is the weight $(\mathrm{g})$ at time $t$.

- $m_{t+10}$ is the weight $(\mathrm{g})$ of the sample $10 \mathrm{~s}$ later.

- $\quad m_{t 0}$ is the weight $(\mathrm{g})$ of the sample at time 0 .

\section{RESULTS AND DISCUSION}

Results of the experiment point out the difference between thermally modified spruce wood treated with fire retardant and non-fire retardant treated wood (please see Table 3). Weight loss was the first non-standardized evaluation criterion. The chart shows that - with the thermally modified fire retardant treated spruce wood - the higher the temperature was, the more efficient it became. 
Table 3: Basic Statistical characteristics evaluation the effect of thermal treatment and retarder on the values of the monitored characteristics.

\begin{tabular}{|c|c|c|c|c|c|}
\hline Effect & $\begin{array}{l}\text { Sum of } \\
\text { squares }\end{array}$ & $\begin{array}{l}\text { Degrees of } \\
\text { freedom }\end{array}$ & Variance & \begin{tabular}{|l} 
Fisher's \\
F-test
\end{tabular} & $\begin{array}{l}\text { Significance } \\
\text { level } P\end{array}$ \\
\hline \multicolumn{6}{|c|}{ Weight loss s (\%) } \\
\hline Free term & 612.948 & 1 & 612.948 & 273.631 & 0.000 \\
\hline Thermal modification & 6.122 & 3 & 2.041 & 0.911 & 0.447 \\
\hline Retarder & 8.319 & 1 & 8.319 & 3.714 & 0.063 \\
\hline $\begin{array}{l}\text { Thermal modification } \\
\text { and Retarder }\end{array}$ & 5.476 & 3 & 1.825 & 0.815 & 0.495 \\
\hline Error & 71.682 & 32 & 2.240 & & \\
\hline \multicolumn{6}{|c|}{ The maximum speed of burning $\left(\% . \mathrm{s}^{-1}\right)$} \\
\hline Free term & $38,041.757$ & 1 & $38,041.757$ & 67.660 & 0.000 \\
\hline Thermal modification & 985.949 & 3 & 328.650 & 0.585 & 0.630 \\
\hline Retarder & $11,984.059$ & 1 & $11,984.059$ & 21.315 & 0.000 \\
\hline $\begin{array}{l}\text { Thermal modification } \\
\text { and Retarder }\end{array}$ & 755.664 & 3 & 251.888 & 0.448 & 0.720 \\
\hline Error & $17,991.940$ & 32 & 562.248 & & \\
\hline \multicolumn{6}{|c|}{ The time to reach the maximum speed of burning (s) } \\
\hline Free term & $2,083,010$ & 1 & $2,083,010$ & 209.646 & 0.000 \\
\hline Thermal modification & 27,465 & 3 & 9155 & 0.921 & 0.442 \\
\hline Retarder & 30,914 & 1 & 30,914 & 3.111 & 0.087 \\
\hline $\begin{array}{l}\text { Thermal modification } \\
\text { and Retarder }\end{array}$ & 61,409 & 3 & 20,470 & 2.060 & 0.125 \\
\hline Error & 317,947 & 32 & 9936 & & \\
\hline \multicolumn{6}{|c|}{ Ratio of the maximum speed of burning (\%) } \\
\hline Free term & 3.898 & 1 & 3.898 & 6.139 & 0.019 \\
\hline Thermal modification & 2.336 & 3 & 0.779 & 1.226 & 0.316 \\
\hline Retarder & 1.898 & 1 & 1.898 & 2.989 & 0.093 \\
\hline $\begin{array}{l}\text { Thermal modification } \\
\text { and Retarder }\end{array}$ & 1.180 & 3 & 0.393 & 0.619 & 0.608 \\
\hline Error & 20.317 & 32 & 0.635 & & \\
\hline
\end{tabular}

The lowest weight loss $-2,25 \%$ - has been recorded with thermally modified spruce wood in combination with a flame retardant at the temperature of $210^{\circ} \mathrm{C}$ compared with thermo-treated wood without any fire-retardant coating (4.31\%). The difference in weight loss between the two types of modifications is approx. $2 \%$. It is followed by thermally modified fire retardant treated wood at the temperature of $180^{\circ} \mathrm{C}$ with the weight loss of 3 , 
$78 \%$ and $160^{\circ} \mathrm{C}$ with the weight loss of $3.88 \%$. Unmodified spruce wood in combination with a flame retardant has the weight loss of $4,72 \%$ after 10 minutes from the beginning of the experiment, but we can see the difference between the samples treated with a flame retardant and the non-treated ones (please see Table 4).

The chart clearly shows that fire retardant increases the ability to resist fire and ignition of thermally modified spruce wood in case of a fire. This result also confirms statistical evaluation of weight loss for thermally modified spruce wood when comparing the samples of treated and non-treated wood (please see Fig. 3).

Table 5 shows the results of ANOVA evaluating the effect of thermal modification of wood on the monitored characteristics. Based on the significance level 'P', we can conclude that the degree of thermal treatment of wood has demonstrated statistically significant effects only on the values of observed characteristics Weight Loss - $600 \mathrm{~s}(\%)$, in other cases the effect was no significant influence of thermal treatment on the monitored characteristics.

Table 4: Weight loss comparison between thermally modified fire retardant treated spruce wood (S) and non-treated wood (P).

\begin{tabular}{|l|l|l|l|l|}
\hline $\begin{array}{l}\text { Thermal } \\
\text { modification }\end{array}$ & $20^{\circ} \mathrm{C}$ & $160^{\circ} \mathrm{C}$ & $180^{\circ} \mathrm{C}$ & $210^{\circ} \mathrm{C}$ \\
\hline $\mathrm{P}$ & 4.72 & 3.98 & 4.48 & 4.31 \\
\hline $\mathrm{S}$ & 4.40 & 3.88 & 3.78 & 2.25 \\
\hline
\end{tabular}

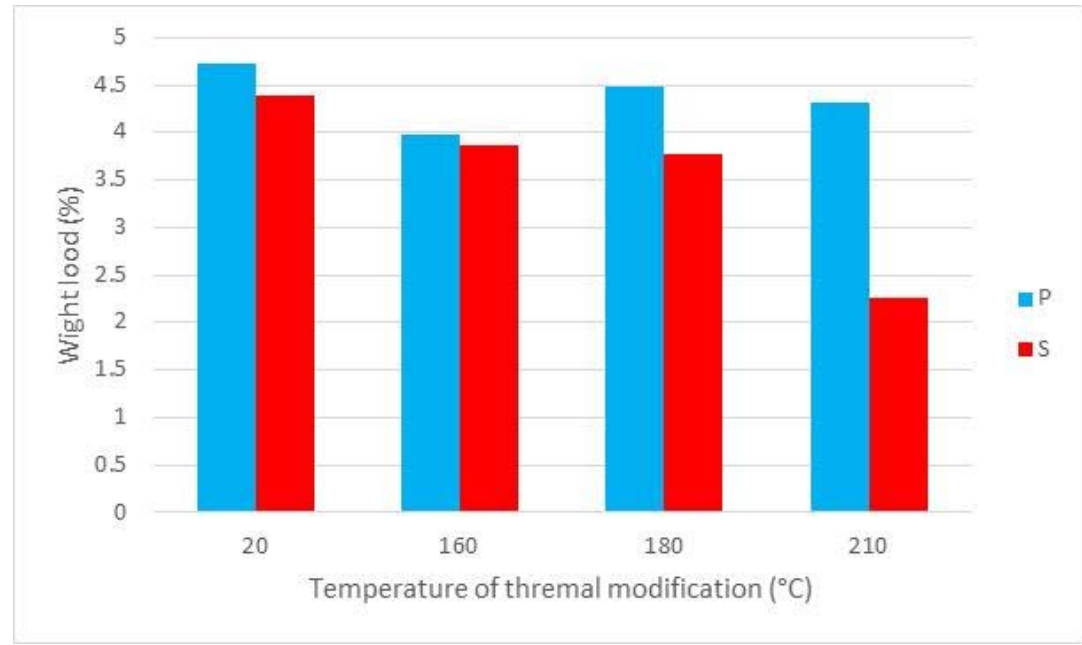

Figure 3: Weight loss comparison of thermally modified spruce wood and thermally modified fire retardant treated spruce wood. 
Table 5: Comparison of burning rate values between thermo-modified fire retardant treated spruce wood sample (S) and non-treated sample (P).

\begin{tabular}{|l|l|l|l|l|l|}
\hline $\begin{array}{l}\text { Thermal } \\
\text { modification }\end{array}$ & $20^{\circ} \mathrm{C}$ & $160^{\circ} \mathrm{C}$ & $180^{\circ} \mathrm{C}$ & $210^{\circ} \mathrm{C}$ & $210^{\circ} \mathrm{C}$ \\
\hline $\mathrm{S}$ & 18.9 & 17.78 & 34.08 & 36.81 & 36.81 \\
\hline & 12.40 & 12.56 & 15.36 & 6.15 & 6.15 \\
\hline
\end{tabular}

Burning rate was the second evaluation criterion. The results correspond with the results of weight loss being the evaluation criterion (please see Fig. 4). The highest burning rate was recorded with thermally modified spruce wood at the temperature of $210^{\circ} \mathrm{C}$ which began to burn intensively. On the other hand, we recorded the lowest burning rate and no spontaneous burning at the temperature of $210^{\circ} \mathrm{C}$ for thermally modified spruce wood treated with a fire retardant. In this case, the fire retardant and its positive effect on the thermally modified spruce wood was considerable. Burning rate of thermally modified spruce wood at the temperature of $180^{\circ} \mathrm{C}$ - the highest burning rate occurred between 140th and 160th second of the experiment.

At $160^{\circ} \mathrm{C}$, thermally modified spruce wood showed a similar burning rate as the non-treated spruce wood at the temperature of $20^{\circ} \mathrm{C}$. The last burning rate increase occurred in 10th minute at the end of flame source exposure and the burning rate fell off afterwards. In all of the cases, the effect of the fire retardant is clear in terms of burning rate reduction (even with thermally non-modified wood, we can see the difference between fire retardant treated and non-treated thermally retarded spruce wood, with a positive outcome for the fire retardant treated sample).

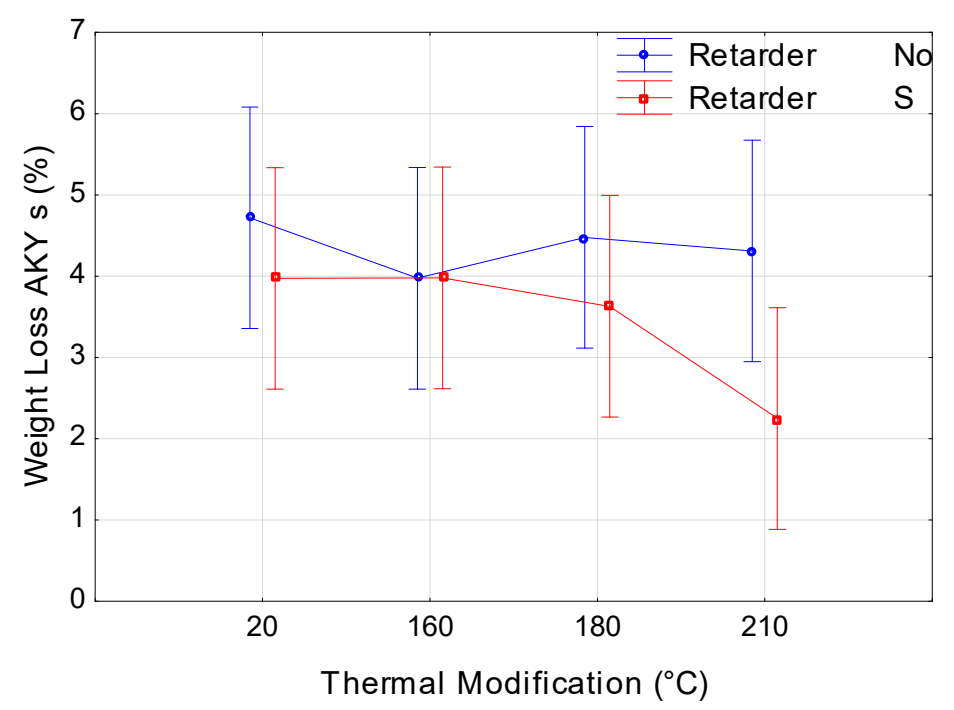

Figure 4: The effect of thermal modification and retarder on the weight loss (\%.s-1). 
On the basis of the results (please see Figs 5 and 6), we have reached the following conclusions.

The experiment confirmed the suitability of the methodology for the ignition of thermally modified spruce wood. The method has proven to be sufficiently sensitive to assess the changes that have occurred with thermally modified wood. One of the interesting findings is the amount of fire retardant (dry matter) absorbed into every single thermally modified spruce wood sample.

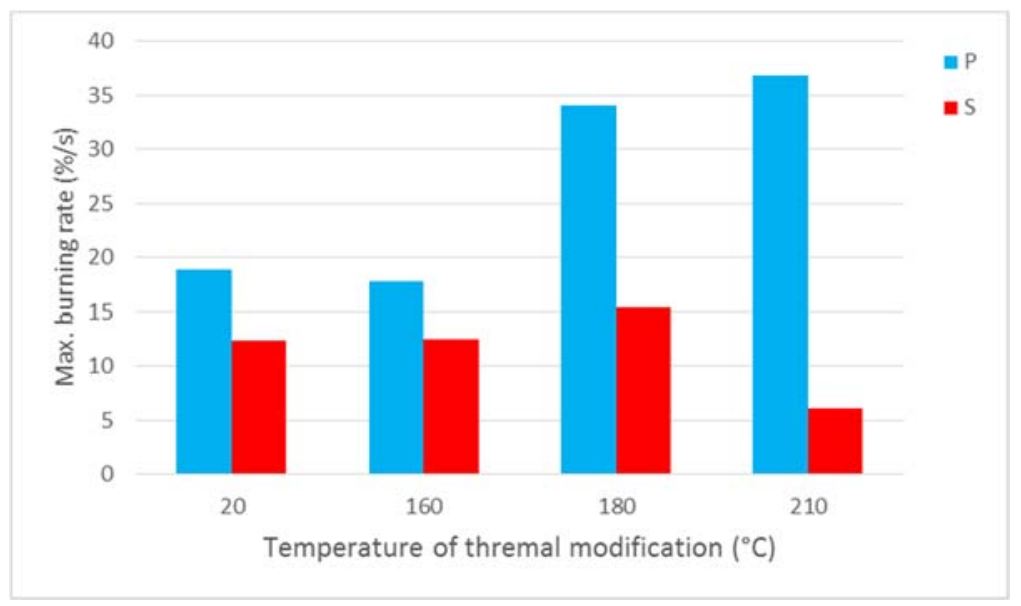

Figure 5: Burning rate comparison of thermo-modified fire retardant treated spruce wood sample.

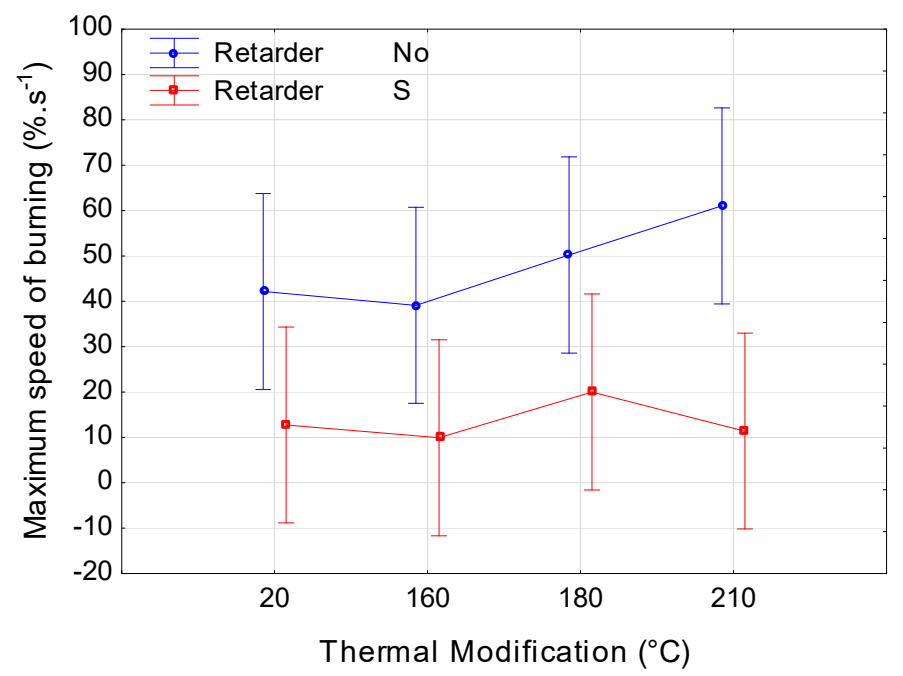

Figure 6: The effect of the thermal modification and retarder on the maximum speed of burning (\%.s-1). 
Table 6: Weight comparison of fire retardant coating in wet and dry condition.

\begin{tabular}{|l|l|l|l|}
\hline $\begin{array}{l}\text { Thermal } \\
\text { modification } \\
\text { temperature }\end{array}$ & $\begin{array}{l}\text { Weight of the } \\
\text { coating when } \\
\text { wet }\end{array}$ & $\begin{array}{l}\text { Weight of } \\
\text { the coating } \\
\text { after drying }\end{array}$ & Dry matter \\
\hline$\left({ }^{\circ} \mathrm{C}\right)$ & $\left(\mathrm{g} / \mathrm{m}^{2}\right)$ & $\left(\mathrm{g} / \mathrm{m}^{2}\right)$ & $(\%)$ \\
\hline \hline 20 & 103.65 & 67.42 & 65.04583 \\
\hline 160 & 101.31 & 86.23 & 85.11499 \\
\hline 180 & 110.04 & 97.31 & 88.43148 \\
\hline 210 & 105.69 & 99.04 & 93.70801 \\
\hline
\end{tabular}

As the chart clearly shows, the weight difference between the coatings before and after drying is minimal. At the temperature of $210^{\circ} \mathrm{C}$, it was less than $7\left(\mathrm{~g} / \mathrm{m}^{2}\right)$.

Samples of thermally modified spruce wood at this temperature $\left(210^{\circ} \mathrm{C}\right)$ have achieved the best results within our evaluation criteria. Weight loss for the samples at the temperature of $210^{\circ} \mathrm{C}$ was around $7 \%$ (please see Table 6). When it comes to burning rate, the effect of fire retardant at this temperature of thermal treatment is obvious.

The highest burning rate has been reached with the samples of thermally modified spruce wood at $210^{\circ} \mathrm{C}$. On the other hand, the very same samples, however, treated with a fire retardant, had the lowest burning rate.

The results clearly show that thermally modified fire retardant treated spruce wood has, at any temperature, lower weight losses than non-treated spruce wood. For all practical purposes, retardant can improve the properties of thermally modified spruce wood for fire protection use.

\section{ACKNOWLEDGEMENTS}

The authors are grateful for the support of the Grant Agency at the Faculty of Forestry and Wood Science, project No. A 12-16.

This work was supported by the Slovak Grand agency VEGA. (Project 1/022/16|6| Fire safe insulation systems based on natural materials.)

\section{REFERENCES}

[1] Akkus, M., Bahcegul, E., Ozkan, N. \& Bakir, U., Post-extrusion heat treatment as a facile method to enhance the mechanical properties of extruded xylan based polymeric materials. RSC Advances, 4, pp. 62295-62296, 2014. DOI: 10.1039/c4ra10478a.

[2] Barvik, Š., Gašparík, M. \& Razumov, E., Effect of temperature on the color changes of wood during thermal modification. Cellulose Chemistry and Technology, 49(9-10), pp. 789-798, 2015.

[3] Welzbacher, C.R. \& Rapp, A.O., Durability of thermally modified timber from industrial-scale processes in different use classes: Results from laboratory and field tests. Wood Material Science and Engineering, 2(1), pp. 4-14, 2007. DOI: 10.1080/17480270701267504.

[4] ISO 13061-1. Wood-determination of moisture content for physical and mechanical tests. International Organization for Standardization, Geneva, Switzerland, 2014.

[5] Čekovská, H., Gaff, M., Osvald, A., Kačík, F., Kubš, J. \& Kaplan, L., Fire resistance of thermally modified spruce wood. BioResources, 12(1), pp. 947-959, 2017. DOI: 10.15376/biores.12.1.947-959. 
[6] Kacik, F., Velková, V., Smira, P., Nasswettrova, A., Kacikova, D. \& Reinprecht, L., Release of terpenes from fir wood during its long-term use and in thermal treatment. Molecules, 17(8), pp. 9990-9999, 2012. DOI: 10.3390/molecules17089990.

[7] Kacikova, D., Kacik, F., Cabalova, I. \& Durkovic, J., Effects of thermal treatment on chemical, mechanical and colour traits in Norway spruce wood. Bioresource Technology, pp. 144-669, 2013. DOI: 10.1016/j.biortech.2013.06.110.

[8] Razumov, E.Y. \& Mikryukova, E.V., The wood with improved properties nanothermowood. SWorld - Modern Problems and Ways of their Solution in Science, Transport, Production and Education, Odessa, Ukraine, pp. 858-868, 2012.

[9] Tjeerdsma, B.F., Boonstra, M., Pizzi, A., Tekely, P. \& Militz, H., Characterisation of thermally modified wood: Molecular reasons for wood performance improvement. Holz als Roh-Werkstoff, 56(3), pp. 149-153, 1998. DOI: 10.1007/s001070050287.

[10] Martinka, J., Kačíková, D., Rantúch, P. \& Balog, K., Investigation of the influence of spruce and oak wood heat treatment upon heat release rate and propensity for fire propagation in the flashover phase. Acta Facultatis Xylologiae Zvolen, 58(1), pp. 5-14, 2016. DOI: 10.17423/afx.2016.58.1.01.

[11] Welzbacher, C.R. \& Rapp, A.O., Durability of Different Heat treated Materials from Industrial Processes in Ground Contact. International Research Group on Wood Preservation: Stockholm, 2005.

[12] Phuong, L.X., Shida, S. \& Saito, Y., Effects of heat treatment on brittleness of Styrax tonkinensis wood. Journal of Wood Science, 53(3), pp. 181-186, 2007. DOI: 10.1007/s10086-006-0841-0.

[13] Metsä-Kortelainen, S., Paajanen, L. \& Viitanen, H., Durability of thermally modified Norway spruce and Scots pine in above-ground conditions. Wood Material Science and Engineering, 6(4), pp. 163-169, 2011. DOI: 10.1080/17480272.2011.567338.

[14] Voronin, B.Y., Nanodrevesina - nanokompozit drevesini - innovacionniy stroitelniymaterialXXIveka, 2012. http://www.nanonewsnet.ru/articles/2011/ nanodrevesina-nanokompozit-drevesinyinnovatsionnyi-stroitelnyi-material-xxi-veka. Accessed on: 4 Jan. 2014. 